PULINKA Ágnes

\title{
A SZERVEZETI VÁLTOZÁSSAL SZEMBENI ELLENÁLLÁS MINT TERMÉSZETES ÉS SZÜKSÉGSZERÜ GYÁSZFOLYAMAT
}

A változás mint szervezet- és vezetéstudományi téma már régóta divatos, de napjainkra lett megkerülhetetlen azok számára, akik szervezetekkel vagy szervezetekben dolgoznak. A változással való személyes, érzelmi megküzdés és a gyászfolyamat közötti erôteljes hasonlóság sem újdonság, de a gyász egyik legismertebb nemzetközi szakértôje, Elizabeth Kübler-Ross modelljének explicit vezetéstudományi alkalmazása a magyar szakirodalomban eddig hiánynak mutatkozott. A szerző cikkében ezt kívánja pótolni, s kifejezetten a vezetéstudomány és a változásmenedzsment aspektusából járja körbe a modellt. Milyen érzelmi reakciókra számíthat a vezető egy változási folyamatban a munkatársai részéről? Miért természetesek és szükségszerúek ezek a reakciók? Milyen megfontolásokat kell ezek tükrében tennie a különbözó változásmenedzsment-lépések alkalmazásakor? Mire figyeljen, és mit kerüljön el mindenképpen? Ezekre a kérdésekre igyekszik válaszolni a szerzó egy folyóiratcikk adta terjedelmi korlátok között tudományos alapossággal.

\section{Kulcsszavak: gyász, Elizabeth Kübler-Ross, változás, változásmenedzsment, ellenállás}

Az egyik leggyakrabban hangoztatott megállapítás korunkkal kapcsolatosan, hogy a változás szerves részévé vált a mindennapjainknak, és nincs olyan szervezet, vezető vagy munkavállaló, akit ne érintene, akinek ne kellene felkészültnek lennie a változásra. Napjainkban ugyanis a gazdasági-technológiai közeg annyira turbulenssé vált, hogy a folyamatos, operatív és stratégiai szintú adaptációs képesség már nem egyszerúen a versenyelőny, de a szervezetek, és vezetőik túlélésének kritikus letéteményese. A változásmenedzsment-ismeretek, a változás dinamikájával, sikertényezőivel és buktatóival kapcsolatos tudás vezetői szinten alapkövetelménnyé vált (Kotter, 2012; Burnes - Jackson, 2011; Drucker, 2001; Robbins et al., 2010; Armenakis - Harris, 2009; Jaros, 2010). Ennek megfelelően évtizedek óta jelennek meg az újabb és újabb változásmenedzsment-elméletek (Kerber - Buono, 2005; Dobák, 1996), amelyek ha nem is végső csodaszert, de valamilyen szintú sikert ígérnek az azokat elsajátító, alkalmazó vezetők számára. Ehhez képest a McKinsey 2008-as globális felmérése azt mutatja, hogy a szervezeti változások két-harmada (!) kudarcba fullad, az azokat kísérő változásmenedzsment-tevékenységek nem érik el a kitûzött céljaikat (Burnes - Jackson, 2011; Burnes, 2011; Sirkin - Keenan - Jackson, 2005; By, 2005; Beer - Nohria, 2000). Fontos különbséget tenni a változásés a válságmenedzsment között. Utóbbi a változás egy speciális esete, de specifikussága miatt külön témaként kell kezelni. Ehhez számos vállalat számára fájdalmas tapasztalatot szolgáltattak azok az események, amelyek a hivatkozott, 2008-as McKinsey tanulmány óta eltelt idő alatt történtek.

A változásmenedzsment gyakorlati és elméleti kutatói számos okot azonosítottak a sikertelenség okaként. A sikertelenség, illetve ennek inverzeként a siker kulcsát a szerzők - többek közt - a következőkben keresik: a vezetői stílus, vezetői eszköztár (Karp, 2006; Karp - Helgo, 2008; Kotter, 2012, 2008; Phelan, 2005; Beer et al., 1990; Beer - Nohria, 2000), a munkavállalók attitúdje (Drzensky et al., 2012; Choi, 2011), motivációja (Morrison - Phelps, 1999), elkötelezettsége (Coetsee, 1999; Jaros, 2010), a középvezetők szerepzavara és a változás értelmezésében játszott jelentőségük (Bryant - Stensaker, 2011), a kommunikációs tevékenységek megfelelősége, illetve nem megfelelősége (Wiggins, 2008; Russ, 2008), a szervezeti és egyén szintú önmegértés, önreflexiós képességek hiánya (Argyris, 1991, 1994; Schein, 1993, 1996), a változási megközelítések és a szervezetek kulturális illeszkedésének elmaradása (Lofquist, 2011), és még sorolhatnánk.

E magyarázó tényezők között nem lehet igazságot tenni, valamilyen rangsort felállítani. Még kevésbé szeretném újabb megoldást ígéró elmélettel gazdagítani az egyébként is hosszú sort. Sokkal inkább kiegészíte- 
ném, árnyalnám az elgondolásokat egy olyan megközelítéssel, amely a változással szembeni egyéni (vezetói és munkavállalói) ellenállást természetes emberi reakcióként magyarázza.

\section{A szervezeti változás}

Paul Watzlavik és szerzôtársai, John Weakland és Richard Fisch, Változás címú „korszakos” (Gerevich, 1989, p. 140.) könyvében a változást úgy definiálják, mint egy nem kívánatos helyzet megváltoztatására irányuló törekvést (Watzlavik et al., 1974). A különböző változás- és változásmenedzsment-megközelítések alapfeltevéseikben (pl. hogyan jellemezhetó, mi pontosan ez a nem kívánatos helyzet, egyáltalán ki határozza meg azt, hogy egy helyzet nem kívánatos stb.) olyannyira különböznek (By, 2005; Kerber - Buono, 2005, 2010; Burnes, 2011; Pettigrew et al., 2001), hogy az egyetlen közös alap, amelyik mindegyikben azonos a változás meghatározásakor az, hogy a változás során végül valamit máshogy csinálunk (Robbins et al., 2010).

Szervezeti keretek között konkretizálva ezt a definíciót, szervezeti változásnak tekintjük azt, amelynek eredményeképpen megváltozik a szervezetek valamely lényeges jellemzője, úgy mint múködési folyamatok, technológia, outputok, struktúra, hatalmi viszonyok, kultúra (Dobák, 1996; Bakacsi, 2004). Hogy konkrétan mit tekinthetünk egy szervezet esetében lényeges jellemzónek, az az adott szervezettől, s az azt körülvevő kontextustól függ (Csedő, 2006).

A szervezeti változások idózitését, szándékoltságát, terjedelmét, mértékét, hatókörét, sebességét, környezethez való viszonyát tekintve több szervezetiváltozás-felfogás él párhuzamosan a szakirodalomban. A hagyományos iskolák a szervezeteket kontingenciaelméleti (Kieser, 1995) alapon közelítik meg, s megkülönböztetik a szervezetek proaktív (környezet által definiált feltételrendszer megváltoztatását célzó), preaktív (környezeti változásoknak elébe menő) és reaktív (környezeti változásokhoz alkalmazkodó, adaptív) változásokat (Gelei, 1996; Bakacsi, 2004). A változások szervezeten belüli terjedelme, mértéke, hatóköre és az érintett hierarchikus szintek ${ }^{1}$ alapján különbséget lehet tenni az inkrementális és radikális változások között (Dobák, 1996; Bakacsi, 2004; Csedő, 2006). Ezek közül az elóbbi egyfajta fokozatosságot, „lépésról lépésre történő" (Bakacsi, 2004, p. 279.) változást jelent, míg a radikális több szervezeti jellemző alapján is nagyobb kiterjedésú változást takar (Gelei, 1996; Dobák, 1996; Bakacsi, 2004; Csedő, 2006).

A változások leggyakoribb megkülönböztetése a változás két alaptermészete mentén történik: a változás tempója/sebessége alapján megkülönböztethetô az epizodikus és a folyamatos változás (By, 2005), a vezetői szándék (a változás feletti kontroll) alapján pedig a szándékolt és a nem szándékolt változás. A szándékolt-nem szándékolt dichotómia az alapján különböztethető meg, hogy a vezetők tudják-e, akarják-e tervezni, irányítani, menedzselni, bármilyen módon tudatosan kontrollálni a változási folyamatot (Cummings - Worley, 2001; Kerber - Buono, 2005, 2010).

A változásmenedzsment-elméletek többsége a szándékolt változásokat helyezi a fókuszba, hiszen elsősorban ezekre a tervezett és szándékolt változásokra lehet előre és tudatosan készülni vezetői szinten. Napjainkban azonban egyre nagyobb népszerúségnek örvendenek azok a változásmenedzsment-megközelítések, amelyek azt nem egy elöre eltervezett folyamatként, nem vezetői sorvezetóként, vagy egyfajta projektként fogják fel, hanem alapvető szervezeti kompetenciaként. Ezek az elméletek azt hangsúlyozzák, hogy a környezetünkre jellemzó folyamatos változás miatt a változás mint képesség, és a változás mint folyamatos tanulás az, ami a siker letéteményese, de legalábbis fokméróje (Robbins et al., 2010; Schein, 1993, 1996; Edmonson, 1996).

Akárhogyan is értelmezzük a szervezeti változás jelenségét, elmondhatjuk, hogy e változási, tanulási folyamatokat egyéni (munkavállalói) szinten kivétel nélkül valamilyen ellenállás kíséri (Bakacsi, 2004).

\section{A szervezeti változásokkal szembeni egyéni ellenállás okai}

A szervezeti változásokkal szemben tapasztalt ellenállásban megkülönböztethetünk szervezeti és egyéni okokat is (Bakacsi, 2004). Mivel jelen cikkünk alapvetően a változással szembeni egyéni reakciókra ad egy magyarázatot, ezért most a szervezeti szintú ellenállás formáival és okaival nem foglalkozunk (ezekért bővebben lásd Bakacsi, 2004, p. 283-286.).

A szervezetekben jelen lévő egyének, mint minden emberi lény, ösztönösen stabilitásra, biztonságra, integrációra és komfortra törekszenek. A változás valami újdonság, ami bizonytalansággal jár együtt, így felborul a megszokott, és alapvetôen billenti ki az egyént a komfortzónájából. Emiatt ösztönösen ellenállunk minden változásnak. „A köznapi élet, valamint a pszichológiai és szociológiai kutatások tapasztalatai egyaránt azt mutatják, hogy az ember természeténél fogva kerüli a változásokat. A változásokkal szembeni idegenkedés mélyen emberi dolog, és alapösszetevőiben pszichológiai törvényszerúségekre vezethető vissza" (Bakacsi, 2004, p. 281.).

$\mathrm{Az}$ idegenkedésünk oka általánosságban lehet az ismeretlentôl való félelem, a bizonytalanságkerülés, a kiszámíthatóság, a megszokott rutinok fenntartására való igény, vagy különböző hárító mechanizmusok („Ezt ti találtátok ki, nem az én problémám.”). További okként 


\section{A szervezeti változással szemben tapasztalt ellenállás: 50 érv a változással szemben}

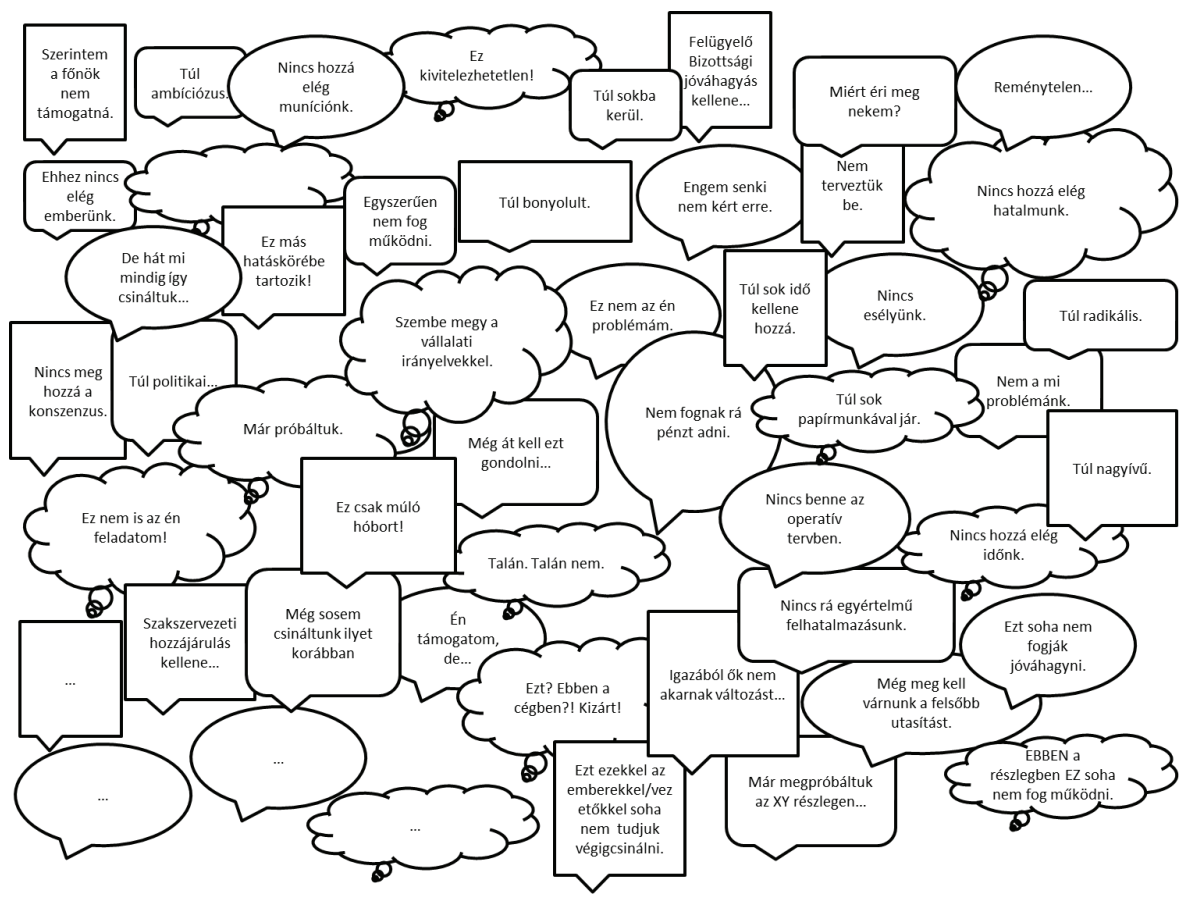

Forrás: www.rebelsatwork.com ${ }^{2}$ alapján készített saját ábra 1.ábra (Wiggins, 2008)! Egy gyászfolyamat bemutatásához könnyú olyan példákhoz nyúlni, mint valamely szerettünk, vagy munkahelyünk elvesztése, de az érzelmi folyamat főbb sajátosságai éppúgy jellemzőek ránk akkor is, ha pl. egy új munkahelyre való belépésre adott egyéni, személyes reakcióinkat elemezzük ezen a szemüvegen keresztül.

A szervezeti változás folyamatában nemcsak a munkavállalók, vagy a középvezetők azonosíthatóak, mint egyének, mint olyan entitások, akik emberi lények, s ezért az emberi lélek sajátjai, így a veszteséggel járó gyászfolyamat is érvényes rájuk nézve. Maguk a vezetók sem vezetói gépezetek, felmerülhet egyszerúen a lustaság, a bizalmatlanság, vagy olyan konkrét félelmek, mint a munkahely elvesztése, vagy az anyagi érdekek sérülésétől való, akár jogos félelem (Bakacsi, 2004). Néhány, szervezeti közegben a változással szemben elhangzó érvet szemléltet az 1. ábra.

Mindezeken túl ellenállásként azonosíthatunk olyan természetes, a változással járó emberi reakciót is, amelyek az embervoltunk, emberi létünknek sajátjai, és szükségszerúen jelentkeznek bármilyen (személyes, magánéleti, szervezeti, társadalmi-politikai) változással kapcsolatban mindannyiunk esetében. Ezek a reakciók tehát nem klasszikus értelemben vett ellenállás-jelenségek, de tüneteiket tekintve könnyú őket akként értelmezni. Valójában egyfajta gyászfolyamatoknak lehetünk esetükben tanúi, ami egy természetes velejárója a változási folyamatoknak, hiszen ha valami változik, akkor az azt is jelenti, hogy valami elmúlik. A változás, még ha szervezeti is, szükségszerúen jár együtt veszteséggel, egyéni szinten veszteségélménnyel. Ezeket a természetes emberi veszteségreakciókat értelmezi és mutatja be összefoglalóan egy svájci orvos, Elizabeth Kübler-Ross modellje, s cikkünk középpontjában ennek a - kutatásokon alapuló - elméletnek a bemutatása és szervezeti változások esetében való interpretációja áll.

A változással járó veszteségérzés és gyászreakciók akkor is fennállnak, ha pozitív változásról van szó rájuk is vonatkoznak azok az általános megállapítások, amelyeket a szervezetet alkotó egyénekre teszünk. A szervezeti ellenállással foglalkozó kutatások hajlamosak elfeledkezni arról a tényről, hogy a változásoknak maguk a vezetôk is ellenállnak. Gelei András, egyetemi docens, szervezetkutató és szervezeti tanácsadó hangsúlyozza változásmenedzsmenttel foglalkozó előadásaiban, hogy vezetőként érdemes tudatosítanunk, hogy mi magunk is sokszor ellenállunk a változásban, ha nem is a változás végső céljaiban (Gelei, 2007).

Ilyetén megfontolásból a jelen cikkben taglalt egyéni dinamika, a szervezeti változással szembeni érzelmi reakciók, s ennek folyamata nem csak a munkavállalói szinten értelmezhetó. Érdemes ezen a szemüvegen keresztül is olvasni az alábbi sorokat!

\section{Elizabeth Kübler-Ross gyászmodellje}

Elizabeth Kübler-Ross (1926 - 2004) svájci pszichiáter, orvosként és kutatóként az Egyesült Államokban tevékenykedett. Hosszú éveken át tanulmányozta a haldoklás folyamatát, a gyógyíthatatlan betegek halálhoz való hozzáállását, ennek változását (Kübler-Ross, 1988). Ezekből a megfigyeléseiből, a rengeteg, elsősorban haldoklókkal folytatott beszélgetéseiből született az a könyve, amely On Death and Dying címmel jelent meg 1969-ben³ s amely ôt elismert kutatóvá tette. 
Kutatása során figyelte meg, hogy a haldoklók nagyjából hasonló érzelmi reakciókat élnek át a haldoklásuk során. Ezek a fázisok a Tagadás, a Düh, az Alkudozás, a Depresszió és végül az Elfogadás (Kübler-Ross, 1988). A fázisokat nevezi azóta is a szakirodalom (Bolden, 2007) a halál és a haldoklás öt szakaszának ${ }^{4}$.

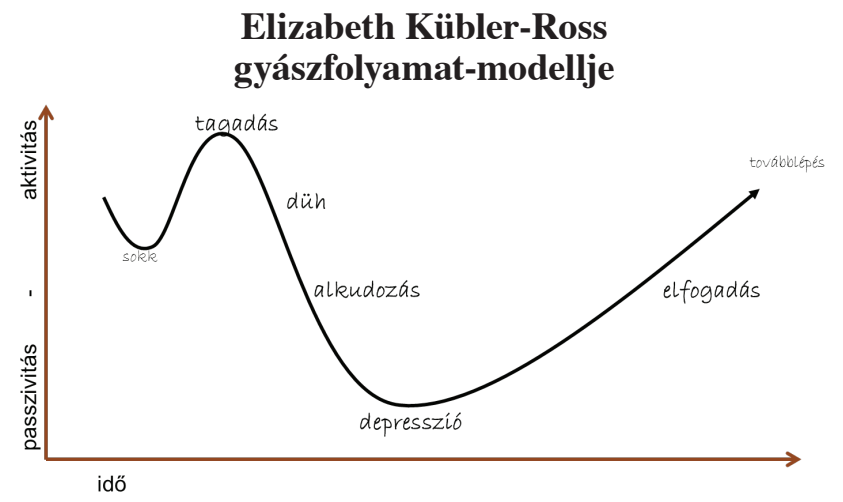

Forrás: Kübler-Ross (1988), valamint Kübler-Ross - Kessler (2005) alapján készített saját ábra

Munkásságának későbbi szakaszában a professzorasszony figyelme a haldoklókról azokra az egyénekre terelődött, akik elvesztették szeretteiket. A velük való közös munka során jutott arra a megállapításra, hogy a fenti szakaszok a gyász folyamatában is pontosan megjelennek. A Tagadás, Düh, Alkudozás, Depresszió, Elfogadás lépésein azok is keresztülmennek, akik gyászolnak valakit (Kübler-Ross - Kessler, 2005).

Kübler-Ross hangsúlyozza írásaiban, hogy ezeknek a szakaszoknak a mélysége, a depressziós mélypont súlyossága, a gyász folyamatának ideje (sebessége), az egyes fázisok hossza, s mindennek a külvilág felé való kifejeződése egyénről egyénre változik (Kübler-Ross Kessler, 2005). (2.ábra)

A modellel kapcsolatos további kutatások (Leming - Dickinson, 2007) arra is rávilágítottak, hogy az azonosított gyászfázisokon eltéró sorrendben mehetnek keresztül az érintettek, nincs kőbe vésve a szakaszok sorrendje, sőt, előfordulhat, hogy valamelyikünknél egyik vagy másik fázis teljesen kimarad.

1. TAGADÁs. Azzal együtt, hogy tudatában vagyunk annak, hogy egy szerettünk meghalt, majdnem mindannyian átélünk egyfajta szimbolikus tagadást. Nehezen hisszük el, nehezen fogjuk fel a tényt, vagy azon kapjuk magunkat, hogy várjuk, megcsörrenjen a telefon, és ố szól hozzánk a vonal túlvégén, nap végén várjuk, hogy hazaérkezzen, és belépjen az ajtón, vagy ösztönösen nyúlunk a telefon után, ülünk le a számítógép elé, hogy kérdezzünk tőle valamit, s csak később eszmélünk, hogy az illető már nincs közöttünk. Ezek mindmind egyfajta tagadásként értelmezhető reakciók a részünkről.

2. DüH. A dühünket sokszor vetítjük ki az elhunyt szerettünkre. Miért nem vigyázott jobban magára? Miért nem figyelt oda, miért nem hallgatott az orvosokra, ránk, a barátai figyelmeztetéseire? De előfordul, hogy saját magunkat okoljuk a történtek miatt. Mi mért nem figyeltünk jobban oda, miért nem vettük észre (időben) a jeleket, a tüneteket? Miért nem voltunk ott, talán akkor segíteni tudtunk volna? Miért nem töltöttünk vele elég időt?

3. ALKUDOZÁS. Ebben a szakaszban azokat a lehetóségeket, vélt vagy valós kritikus pontokat vesszük számításba, amelyekben a végzetes eseménnyel kapcsolatos kontrollt, egészen pontosan a kontroll illúzióját éljük át. Ezekben a fantáziákban azzal hitegetjük magunkat, hogy befolyásolni tudtuk volna a befolyásolhatatlant, megakadályozhattuk volna az eseményeket. Ha nem engedtem volna autóba ülni... Ha mellette lettem volna... Ha felhívom aznap/előző délután/este/reggel... Ha nem abba a kórházba viszem... Bárcsak kimondtam volna... Bárcsak megkérdeztem volna... Bárcsak... Ha...

4. DEPRESSZIó. A végzetesség, a tehetetlenség, a megváltoztathatatlanság érzelmi megélése történik ebben a fázisban. Az ezzel járó fájdalom, szomorúság természetes velejárói a gyász folyamatának, megélésük szükségszerú ahhoz, hogy a gyógyító fázis elkezdődhessen, s végül a továbblépés megtörténjen.

5. ELFOGADÁs. A gyászoló egyén a veszteséggel együtt felfogja és elfogadja az ôt körülvevő valóságot, kapcsolatba kerül a maga szeretett barát, hozzátartozó nélküli, megváltozott valóságával, világával, életével. Egyre inkább meri és tudja elképzelni a jövőt, amelyben már nincs helye és szerepe az elvesztett egyénnek ${ }^{5}$.

3. ábra

\section{Elizabeth Kübler-Ross gyászmodellje: a fázisok fókuszai}

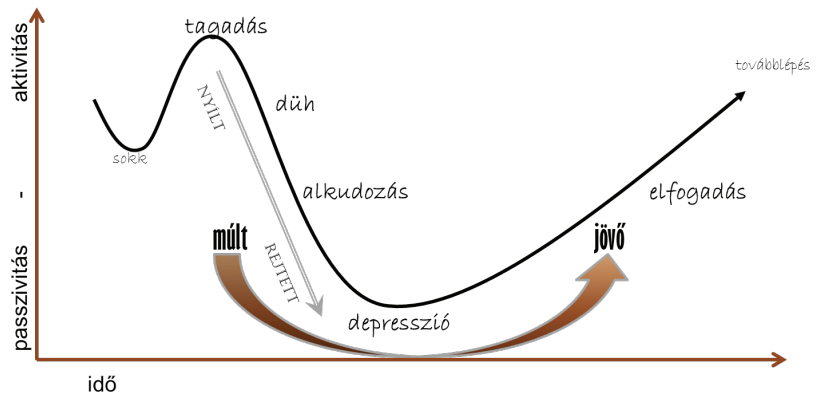

Forrás: Kübler-Ross (1988), valamint Kübler-Ross és Kessler (2005) és Wiggins (2008) alapján készített saját ábra 
A 3. ábrán látható, hogy az első két fázis (1-2) érzelmi reakciói jól azonosíthatóak, mert a gyászoló egyén jól artikuláltan kifejezésre juttatja azokat. Az, hogy a külvilág számára a reakciók észlelhetőek, nagyban megkönnyíti a gyászolóhoz való kapcsolódást, és így a segítségnyújtást is. A következő két szakasz (3-4), az Alkudozás és Depresszió fázisok fontos jellemzője, hogy ezekben a fázisokban a gyászoló fókusza máshol: a múltban vagy a saját belső érzelmi világában van. Az Alkudozás (3) esetében a múltban azonosított vélt vagy valós kritikus pontokon való (ön)emésztés, a Depreszszió (4) esetében a veszteség feletti fájdalom a mindent domináló, személyes élmények. Amikor az egyén nyitott(abb)á válik, kapcsolatba kerül az ôt körülvevő valósággal, figyelme a jelenre, majd a jövőre kezd orientálódni, akkor már elmondhatjuk, hogy a gyászfolyamat mélypontján túljutott.

Elizabeth Kübler-Ross a 2005-ben, David Kessler amerikai haldoklás és gyászszakértővel közösen írt On Grief and Grieving címú könyvében hangsúlyozza, hogy valamilyen személyes veszteséget minden ember átél, azok is, akiknek nem hal meg közeli hozzátartozójuk vagy szerettük. Tehát a fenti gyászfolyamatot (ún. gyászmunkát) mindannyian átéljük, a gyászmunkával kapcsolatos megállapítások így mindannyiunkra érvényesek (Kübler-Ross - Kessler, 2005). Ilyen személyes veszteség minden, különböző életszakaszainkat lezáró esemény, fordulópont, akkor is, ha alapvetóen pozitív a változás (nyugdíjba vonulás, házasságkötés, gyermekszületés, elköltözés otthonról, érettségi, munkahelyváltással járó költözés, új munkahelyre való bekerülés stb.). Ezek az örömteli események egy korszak, időszak, hely veszteségét - tulajdonképpen a régi, kiszámítható világunk felborulását hordozzák magukban.

A bemutatott gyászmodell nemcsak Kübler-Ross-t tette elismert kutatóvá és szakértóvé (Kübler-Ross, 2012), de elméletét rendkívül széles körben alkalmazták is. A veszteséggel - és általában a változással - kapcsolatos megküzdési folyamat, a gyászmunka messze túllépett a pszichológia és a gyógyítás szakterületein (Hisham Hashim et al., 2013), egyaránt építettek erre az elméletre gyakorlati szakemberek és elméleti kutatók. Néhány példa érdekességképpen, a teljesség ígérete nélkül:

$\rightarrow$ sportpszichológia (Poel - Nel, 2011),

$\rightarrow$ pedagógia, családterápia (pl. nevelószüilókhöz kerülő gyerekek érzelmi megküzdéseinek vizsgálata, Fineran, 2012, válási traumák feldolgozása, Gastill, 1996),

$\rightarrow$ az Egyesült Âllamokban a 2001. szeptember 11-i terrorcselekmények társas-társadalmi dinamikáinak értelmezése (Atkinson, 2001),

$\rightarrow$ az Egyesült Államokban egyes banktörvényekkel kapcsolatos szakmai viták kapcsán, valamint a törvények elfogadását követô, pénzügyi szektorban tapasztalt reakciók elemzése (Sausner, 2008),

$\rightarrow$ a nyugdíjba vonulás érzelmi vetületei (Brown, 2013),

$\rightarrow$ elbocsátásokkal járó vezetôii, munkatársi és az elbocsátottak által átélt dinamikák magyarázata (Rogers, 2011),

$\rightarrow$ az Egyesült Államokban az egészségügyi reformokra, az orvosok tervezett teljesítményjelentő rendszerére adott ellenállásának értelmezése (Smaldone - Uzzo, 2013).

A fenti, kiragadott példák közül az utolsó három már éles kapcsolatot mutat a szervezeti változások témájával, ami érthetô, hiszen a modell mint a változással kapcsolatos természetes és szükségszerú egyéni megküzdés értelemszerúen nem hagyhatta érintetlenül a szervezeti kutatásokat, közöttük a szervezeti változásokkal kapcsolatos szakirodalmat sem.

\section{A Kübler-Ross modell alkalmazása szervezeti változásokra}

A változással szembeni személyes ellenállás zsigeri, ösztönös, emberi reakciónk, mindig megküzdéssel jár. Ez a megküzdési folyamat vagy gyászmunka megjelenik akkor is, ha munkavállalóként szervezeti változások érintenek bennünket (Wiggins, 2008; Pataki, 2013). A gyászfolyamaton ezekben az esetekben mindig, minden, változásban közvetett vagy közvetlen módon érintett munkavállaló keresztülmegy. Ahogy korábban a gyászmunkával kapcsolatban hangsúlyoztam, az egyének (a munkavállalók) közötti eltérés a folyamat sebességében, a mélypont mélységében érhetô tetten, illetve különbség lehet az is, hogy nem minden érintett tapasztalja meg a folyamat minden fázisát, elófordulhat, hogy valakinél egyik vagy másik szakasz kimarad. A különbségeket az egyént körülvevő, támogató kapcsolatok minősége (szorossága, intenzitása, számossága, stabilitása), a közeli hozzátartozók támogató jelenléte, az egyén korábbi személyes története, benne az esetleges korábbi megküzdések tapasztalatával, az egyén pszichikai adottságai (Wiggins, 2008) egyaránt okozzák. Értelemszerúen azok a munkavállalók, akik csak közvetetten érintettek egy változásban, kevésbé vagy kevéssé intenzíven élik meg a folyamatot, annak egyes szakaszait. Nézzük végig a fent bemutatott modellt a szervezeti változások kontextusában!

Korábban hangsúlyoztuk, hogy nem csupán a beosztottak, a változások „elszenvedői”, hanem a vezetôk, a változások kezdeményezői, irányítói is keresztülmennek ezeken a szakaszokon. Mindkét szerepben fellelhetók azok a tipikus reakciók, amelyek az egyes, változásokat kísérô gyászállapotok legfőbb jellemzői. Ezekre a reakciókra mutat összefoglalóan példákat az 1. táblázat. 
A szervezeti változásra adott reakciók

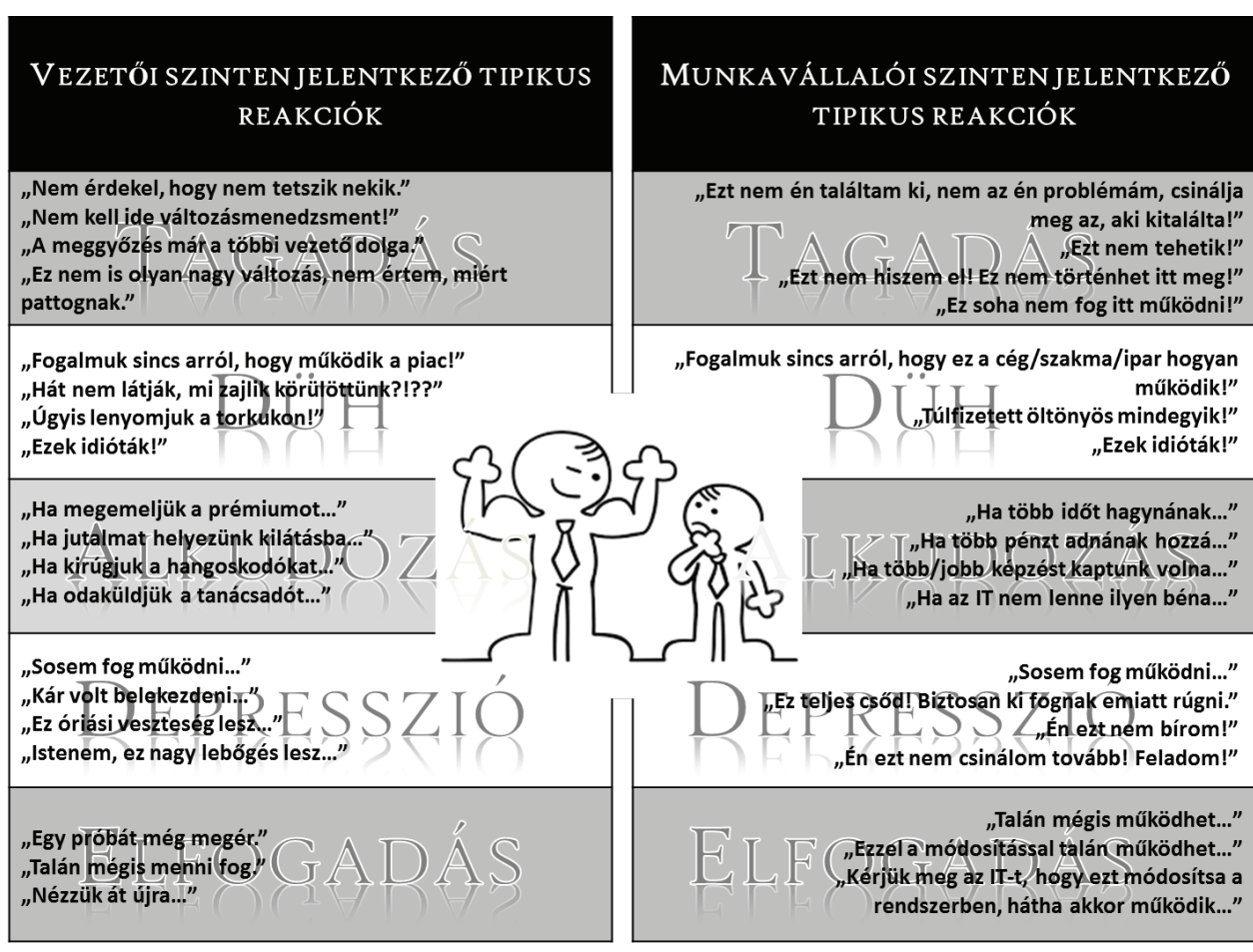

Forrás: Kübler-Ross gyászmodellje szerinti saját táblázat 1.táblázat kifejezés a „munkavállalói hiszti"). Sokszor kivetül, projektálódik, például a vezetôkre, a változás hírével érkező kollegákra, vagy a közremúködő tanácsadókra, vezetők részéről esetleg a munkavállalói érdekvédelem képviselöire („Már megint a szakszervezet...!"). (Wiggins, 2008).

3. ALKUDOZÁS. Legjellemzőbb tetten érni ezt a szakaszt az apró-cseprő ügyeken, problémákon való (túl) hosszú rágódásokban, vagy annak a sorolásában, hogy mi mindenre lenne szükség még, mi minden kellene még (idő, pénz, erőforrások, többlet munkaerő, vezetôi támogatás...) ahhoz, hogy megvalósítható legyen az elvárt változtatás.

Aki dolgozott már szervezetekben, szervezetekkel, és részt vett tanácsadóként, munkavállalóként vagy vezetôként változásokban, bizonyára felismert ismerôs mondatokat az 1. táblázatban, sốt, gyanítjuk, hogy továbbiakkal tudná bővíteni a felsorolásokat. Vezetói szinten legjellemzőbb, hogy a vezetők a beosztottaik reakcióival kapcsolatban mennek keresztül ezen a megküzdési folyamaton.

1. TAGADÁS. Akárcsak a személyes veszteségek megélésénél, szervezeti változás esetében is az elsô reakció a tagadás lehet. A „Nem tehetik meg velem/ velünk.", ,Ez nem történhet meg!”, vagy a „Mindegy, ki találta ki, úgysem lesz belóle semmi.", esetleg „Ez engem úgysem érint.” mondatok mögött mindig tagadás áll: minden rendben volt, jól múködött (de legalábbis múködött) eddig, nincs szükség változásra, nem veszünk róla tudomást.

2. DüH. A változásra való dühös, indulatos reakciók szervezeti közegben főleg frusztráció, szkepticizmus, gyanakvás formájában érhető tetten. „Aki ezt kitalálta, annak fogalma sincs arról, hogy múködik ez a cég/szakma!”, „Könnyü okosnak lenni ott fenn!”, „Ezek biztosan csak indokot keresnek a létszámleépítésre..." A düh nem kell, hogy racionális legyen, de biztos, hogy mindig létezó, érzékelhető jelenség (vezetőktől sokszor hallott
4. DEPRESSZIó. Szervezeti változások esetében a depresszió apátiában, egyéni vagy csoportos izolációban, érdektelenségben mutatkozik meg leginkább. Az egyéni gyász folyamatában is az a veszélyes, hogy ha az egyén benne ragad ebben a fázisban, vagy ha olyan mélypontra kerül, hogy az önmagában való károkozást, netalán az öngyilkosságot fontolgatja. Nyilván szervezeti változások esetében ezek nem (vagy rendkívül ritkán) fordulnak eló, de a szakasz veszélyessége itt is fennáll! Ha sor kerül szabotázsakciókra, akkor azok jellemzően ebben az érzelmi mélypontban történnek (Wiggins, 2008). A szélsőséges megnyilvánulásoktól függetlenül elmondható, hogy ekkor van a munkamorál, a munkateljesítmény a mélyponton. Dominálnak a munkavállalói félelmek, kétségek, a bizalomhiány, a motiválatlanság.

5. ELFOGADÁS. Megjelenik a munkavállalók között a nyitottság az újra, jellemző magatartásként megjelenik a próbálkozás, ötletek kerülnek eló, amelyek a megvalósítás felé mutatnak. Az emberek elfogadják, hogy a változás elkerülhetetlen. Kérdések merülnek fel, a továbblépés felé mutató, tehát proaktív és konstruktív igények fogalmazódnak meg, a változás megoldandó és megoldható problémaként értelmeződik újra a munkatársak között. 
A személyes, magánéleti veszteségeket kísérő gyászfolyamat és a szervezeti változásokat kísérő reakciók Kübler-Ross modell szerinti újraértelmezése, a kettő párhuzamba állítása meglátásunk szerint azért bír jelentőséggel, mert ez a megközelítés hangsúlyoz$\mathrm{za}$, hogy a fent bemutatott egyéni reakciókat teljesen természetes, embervoltunkból adódó érzések okozzák. Sem megszüntetésükre, sem negligálásukra, sem elnyomásukra, elfojtásukra nem érdemes, nem szabad törekedni. Felelös változásmenedzserként, legyünk vezetói, tanácsadói, projektmenedzseri szerepben, fel kell tudni ismerni, melyik szakaszban járnak a munkavállalók. Különös tekintettel kell lenni arra, hogy az egyes munkavállalói csoportok éppen más-más szakaszokban lehetnek, és vezetőként folyamatosan reflektálnunk kell arra is, mi magunk hol tartunk, mi magunk mutatunk-e a változás folyamatával kapcsolatban ellenállást, amely természetes gyászreakcióként értelmezhető. Az általános megállapításon túl több, gyakorlatias konzekvencia is következik a Kübler-Ross modell szervezeti változásokra való adaptációjából, cikkünk záró akkordjaként ezeket foglaljuk össze.

\section{Mit üzen Kübler-Ross gyászmodellje a változásmenedzsment számára?}

Részben már kitértünk Kübler-Ross modelljének a szervezeti változásokkal kapcsolatos néhány gyakorlati aspektusára. A legfontosabb, hogy vezetôként, közremúköőo tanácsadóként vagy projektmunkatársként (projektvezetôként, projektmenedzserként) el kell fogadnunk azt, ha a szervezet tagjai részéről a bemutatott érzelmek bármelyikét észleljük. Ezek a reakciók teljesen természetes emberi sajátosságok, sem az asztalról le-, sem a szőnyeg alá be nem szabad söpörni azokat. Erôszakos, természetes lefolyásukat, dinamikájukat semmibe vevő megszüntetésükkel, elfojtásukkal pedig sokkal több kárt okozunk, mint gondolnánk. Érzelmekről van szó, ha elfojtjuk őket, később hatványozott erővel zúdulhatnak ránk, nem várt helyen és időben!

$\mathrm{Az}$ egyes fázisokban, az adott szakaszokhoz illeszkedő, adekvát válaszlépésekre van szükség. A 4. ábrán látható, hogy a TAGADÁS fázisában arra érdemes törekedni, hogy minél előbb eljusson az érdemi információ az érintettek tudatához, hogy érdemben és mélységében felfogják az őket érintő változásokat. A változások kezdetén nincs olyan, hogy elegendő kommunikáció. A változást, a változás üzenetét újra és újra el kell mondani. Sok vezető reagál úgy az újabb kommunikációs feladatok láttán, hogy „Hát ezt már elmondtam nekik!". Nekik meg kell érteniük, hogy addig kell beszélni a változásról a munkatársaknak, amíg nem tudatosodik bennük annak elkerülhetetlensége (Wiggins, 2008).
Két jelenség okoz kihívást ebben a kezdeti szakaszban. Az egyik az ún. belsố hang ereje. Argyris munkásságára hivatkozva Wiggins (2008) hívja fel a figyelmet arra a jelenségre, hogy létezik egy belsô hang, amely minden, számunkra fontos eseményt, történést kommentál számunkra. Ez nem feltétlenül egyezik meg azzal a reakcióval, amit adott szituációban ki is mondunk. Ha a felettesünktől új projektet kapunk, magunkban reagálhatunk rá úgy, hogy „Hát persze, újabb feladat, amit az én nyakamba sóznak...!", de kevés esetben artikulálódik ez a belső hang hallhatóan a külvilág felé. Sôt, a külvilág (jelen esetben a főnökünk) inkább olyan reakciót kap tőlünk, mint „Nagyszerú, örülök az új kihívásnak!" Ami a belső hang jelensége kapcsán fontos, hogy minél intenzívebben érint bennünket a külvilág eseménye, a belső hang annál hangosabban reagál a fejünkben. „Nem akarom ezt az új projektet! Mit mondok a családomnak? Nem fogom látni a gyerekeimet! Küldjenek mást!" Tulajdonképpen egyszerre ketten beszélnek hozzánk: a fönökünk, aki hozza a hírt, és a belső hangunk, amely annál hangosabb, minél személyesebben és konkrétabban érint bennünket a hír. Egyszerre figyelni érdemben mindkettőre igen-igen keveseknek sikerül, inkább jellemző, hogy a hangosabbra fókuszálunk (amely nyilván a belső hang), vagy felváltva figyelünk egyikre majd a másikra. Akárhogy is, észlelési problémát okoz a jelenség. A belső hang ereje fültépő tud lenni (Wiggins, 2008). Így fordul elő, hogy újabb és újabb kommunikációs akciókra van szükség egy változás kezdetén.

A változási folyamatok kezdetén fontos másik jelenség a változás okainak, miértjeinek eltérô magyarázatai (Wiggins, 2008). Párbeszédekben sokszor lehetünk tanúi annak, amikor az álláspontok megfeneklenek, a felek beássák magukat saját sáncaikba, és se előre, se hátra nem mozdul a folyamat, mindenki a saját végső érvét, álláspontját hangoztatja. Ezekben a helyzetekben az vezet megoldásra, ha minden érintett fél bemutatja, milyen érvek, logika mentén jutott arra a következtetésre, amely álláspontja mögött meghúzódik. Milyen tények, adatok (!) alapján van bizonyos állásponton, ezeket az adatokat hogyan értelmezi, milyen logikai láncolatba fúzi ôket. Tulajdonképpen a saját gondolatmenetén végigvezeti a más állásponton lévó feleket. Szervezeti változások menedzselése szempontjából ennek a fontos relevanciája, hogy nem elég a változások célját, útját, módját elmondani az érintetteknek. Minél érzékenyebb, vagy nagyobb horderejú változásokról van szó, annál alaposabban kell nekik bemutatni, hogy miért hozta meg a vezetés a változásokhoz vezető döntést. A változásmenedzsment-elméletekben ez a „Miért-sztoriként” jelenik meg. Itt azonban érdemes rámutatni arra is, hogy a vezetói „Miért-sztori” hangsúlyozása mellett egy dolog rendre el szokott marad- 
ni: a másik fél sztorijának, ha úgy tetszik, miért-jeinek meghallgatása. A munkatársaknak is lehet tényeken, tapasztalaton alapuló megértése a szervezeti valóságról, s ezeken egy másik következtetésre juthatnak. Nem elég azt elvárni, hogy meghallgassák és megértsék a vezetôk, a változások kezdeményezőinek gondolatmenetét! A változási probléma hasonlóan lényeges tényezője az, ha ôk nem így látják a helyzetet, és ezért esetleg más állásponton vannak, mint a vezetôk. Nincsenek illúzióink afelől, hogy ez mekkora energiákat igénylő munka! De tapasztalatból eredő meggyő̋ódésem, hogy eredményes és tartós változások eléréséhez nélkülözhetetlen vezetői, projektvezetői lépésről van szó. Ha logikusan végiggondoljuk, magától értetődővé is válik: az eltérő megértés legkedvezőbb esetben is csökkent motivációt eredményez, esetleg az elkötelezettség hiányát. Roszszabb esetben, vagy öntudatosabb, önbizalommal rendelkezó munkavállaló esetén azonban akár aktív ellenállást is kiválthat a változások implementálásában.

A $D \ddot{H}$ szakaszában az egyetlen adekvát lépés a munkatársak részéról jelentkező érzések elfogadása, tiszteletben tartása, illetve gyakorlatiasabb oldalról nézve fontos, hogy teret adjunk ezeknek a kifejezésére. A ventillációs technikák igen szerteágazóak. Amire figyelni érdemes, hogy teret biztosítsunk mindenkinek, ne engedjük, hogy néhány (hangosabb, dominánsabb) munkavállaló kisajátítsa a rendelkezésre álló idôt és teret, mindenki, akinek arra igénye van, lehetőséget kapjon a kétségei, ellenérzései, ellenvetései, panaszai kifejezésére és érdemi meghallgatására.

4.ábra

Adekvát változásmenedzsment-tevékenységek a munkavállalók gyászfolyamatának szempontjából

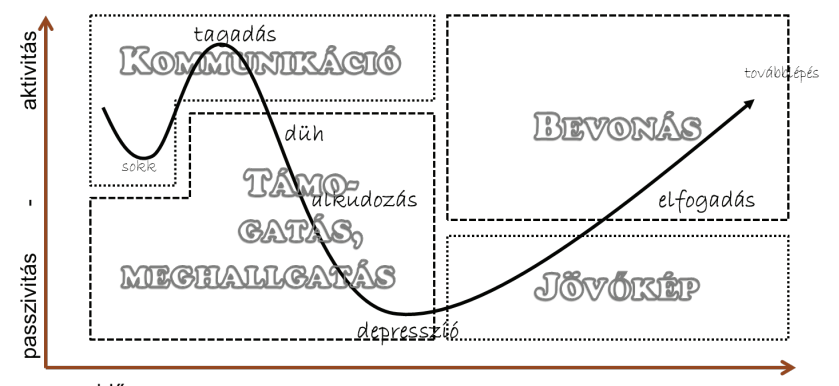

idő

Forrás: Wiggins (2008) alapján készített saját ábra

Az előzőhöz hasonlóan az ALKUDOZÁs szakaszában is az a legmegfelelóbb, ha teret adunk azoknak az igényeknek, észrevételeknek, megjegyzéseknek, amelyek ennek a fázisnak a természetes velejárói. Arra kell figyelni, hogy időben és térben is megfelelően legyen keretezve (korlátozva) a folyamat e része. Az Alkudozás jellemzője, hogy többnyire illúziókon alapszik, ez azonban nem szabad, hogy leegyszerúsítse számunkra, a változás vezetői számára a kapcsolódó tevékenységünket. A legnagyobb veszély, ha valód igényt, észrevételt, kritikát söprünk az asztal alá azzal az érveléssel, hogy ez csak az alkudozási fázis velejárója. Igenis lehet a kritika, igény mögött jogosság! Ennek körüljárásához, megvizsgálásához adekvát módszert biztosítanak a különböző kockázatmenedzsment-megoldások. Ezeknek a közös jellemzője, hogy minden észrevételt megvizsgálnak, értékelnek, kockázat szempontjából kategorizálnak és priorizálnak. Azt üzenik a munkavállalók számára, hogy a felvetéseket a változások vezetői komolyan veszik, vagyis nemcsak a változás iránt elkötelezettek, de a munkatársak felé is nyitottak, érdemben számítanak az aktív közremúködésükre. Fontos az eredmények visszacsatolása, hogy a munkatársak lássák, milyen elemzések, érvelések mentén, milyen válaszok születtek a felvetéseikre, igényeikre.

Ha már a DEPRESSZIó fázisának tüneteit észleljük a munkatárainkon, akkor igazán örülhetünk, bármennyire is ambivalensen hangzik ez. A legfontosabb ennek az érzelmi mélypontnak az elfogadása vezetóként, amely mélypont a teljesítményben, a munkavégzés moráljában is megmutatkozik. Türelem, az érzések alázatos elfogadása, de ugyanakkor odafigyelés is szükségeltetik, hiszen nem szabad hosszú időn át benne ragadni munkavállalóként, munkavállalói csoportként a veszteség feletti (jogos) szomorúság érzésébe. A felettes vezetők személyes példájának jelentősége fontos, előre mutató erőként jelenik meg ebben a fázisban. Amennyiben türelmet, elfogadást és nyitottságot tapasztalnak a vezetők részérôl, sokkal hamarabb válnak a munkatársak nyitottá az új, a jövő felé. Ebben a periódusban lehet igazán fontos, túllendítő ereje egy jól megfogalmazott, változással kapcsolatos jövóképnek. A jövőkép, az új felé megmutatkozó nyitottság már az ELFOGADÁs, de legalábbis az érzelmi mélyponton való túllendülés bizonyítéka. Ha ez a fajta nyitottság tapasztalható a munkatársakon, akkor van érdemi helye annak, hogy bevonjuk őket a jövőkép operatív részleteinek kitalálásába és megvalósításába.

Az egyes gyászfázisok vezetők általi felismerésének, azonosításának jelentősége abban áll, hogy a fázisokban tapasztalható érzelmi állapotnak megfeleló változásmenedzsment-lépést vagy -eszközt alkalmazzunk. Ha pl. a munkatársak a DüH szakaszában vannak, akkor a változási folyamatba való bevonásuk, egy, a változással kapcsolatos jövőkép kidolgozásával foglalkozó workshoppal olaj lehet a túzre, s ami biztos, hogy eredményeket csak azután tudunk velük elérni, ha elóbb érzelmeik kifejezésére teret kapnak. (Ha nem kapnak, akkor teremtenek.) A változással járó veszteség természetes érzelmi mélypontján (DEPREsszió szakasza) pedig ne csodálkozzunk, ha munkatársaink nem látják olyan vonzónak vagy szépnek a változás kommu- 
nikációja során felvázolt jövőképet, amiben vezetőként mi olyannyira hiszünk. Ha munkatársaink a TAGADÁs fázisában vannak, akkor pedig nem fogják érteni, ha a változási folyamat, célok, jövőképpel kapcsolatos kérdéseikről, érzéseikről kérdezzük ốket, hiszen sommás véleményük annyi lesz, hogy változás itt (márpedig) úgysem lesz.

A munkavállalók, munkavállalói csoportok másmás szakaszban lehetnek adott idó pillanatban! Ne várjunk egységes reakciókat, törekedni kell a jellemző motívumok észlelésére, megkülönböztetésére. Nem elvárás, hogy minden munkatársat a maga állapotában, annak megfelelően, egyedileg kezeljünk. De a kulcsérintetteket, a változás szempontjából kritikus, és/vagy domináns szereplóket különös gonddal és odafigyeléssel kell kezelni, lehetőség szerint adott, gyászfolyamatbeli állapotuknak megfelelően, egyedileg menedzselni.

Akár a változásokat irányító vezetôként, akár a változásokban aktívan közremúködő tanácsadóként, projektvezetóként a legfontosabb feladatunk így a munkatársak felé való megértó odafordulás, az aktív figyelem, hogy képesek legyünk azonosítani a tüneteket, különbséget tenni a különféle érzelmi állapotok között. El kell fogadnunk, hogy emberek vagyunk, s a változással járó veszteség, a veszteséggel való megküzdés természetes része emberi létünknek, ha úgy tetszik, a változásokra való érzelmi reakciók emberi jogaink.

Ami ebben a megközelítésben még érdekes, hogy a különféle változásvezetési taktikák (Zaltman - Duncan, vagy a Nutt-féle; Zaltman - Duncan, 1977; Nutt, 1987) azt mondják, hogy az ellenállás természete szerint kell megválasztani a megfelelő változásmenedzsment-taktikát. A cikkben bemutatott elgondolás alapján viszont azt lehet kimondani, hogy a különböző gyászszakaszokhoz különböző taktikák rendelendók. Folyamatában, a munkavállalók adott állapotának megfelelően, dinamikusan alakul a változásmenedzsment.

\section{Összegzés}

Cikkemben azt mutattam meg, hogy a szervezeti változások során minden közvetve vagy közvetlenül érintett munkatárs valamilyen formában keresztülmegy a Kübler-Ross által meghatározott ún. gyászfázisokon. Minden változás szükségszerúen jár veszteséggel, hiszen ha valami megváltozik, akkor már nem lesz minden ugyanolyan, nem lesz a bennünket körülvevő világ ugyanaz, s ezt veszteségként éljük meg. A veszteséggel kapcsolatos megküzdés, ennek érzelmi szakaszai mindenkinél azonosak, különbség elsősorban a folyamat sebességében, az egyes szakaszok sorrendiségében van, valamint előfordulhat, hogy egyikünk-másikunk esetében valamely fázis egyszerúen kimarad. A változásmenedzsment hatalmas eszköztára számára a legfontosabb üzenet, hogy ismerjük fel, munkatársaink épp melyik gyászfázisban vannak, és az annak megfelelő változásmenedzsment-eszközt, -technikát alkalmazzunk. Ehhez alapvetôen szükségeltetik a munkatársakra való érdemi odafigyelés, az érzelmi állapotuk tiszteletben tartása, elfogadása, és az a(z) (vezetối) önreflektív képesség, miszerint vezetôként képesek legyünk felismerni, ha mi magunk ellenállást tanúsítunk, például a munkatársaink változással kapcsolatos természetes és szükségszerú érzelmi reakcióival kapcsolatban.

\section{Lábjegyzet}

${ }^{1}$ További szempontokért és a részletes különbségért lásd Dobák (1996, p.191.), Bakacsi (2004, p. 287.), Csedő (2006, p. 23.)

${ }^{2}$ http://www.rebelsatwork.com/2013/02/20/50-reasons-not-to-change/

${ }^{3}$ Magyarul megjelent 1988-ban, A halál és a hozzá vezető út címmel (Kübler-Ross, 1988).

${ }^{4}$ A modell mutat hasonlóságot a változásmenedzsment-irodalomban jól ismert Virginia Satir változásifolyamat-modelljével. A két modell részben fedi egymást, a részletes összehasonlításért lásd Blevins (2008) cikkét.

${ }^{5}$ Az összeállítás Kübler-Ross (1988), Kübler-Ross és Kessler (2005), Bolden (2007) írásainak felhasználásával történt.

\section{Felhasznált irodalom}

Argyris, C. (1991): Teaching Smart People How to Learn. Harvard Business Review, May/June, Vol. 69. Issue 3.: p. 99 - 109.

Argyris, C. (1994): Good Communication That Blocks Learning. Harvard Business Review, July/August, Vol. 72. Issue 4.: p. 77 - 85.

Armenakis, A. A. - Harris, S. G. (2009): Reflections our Journey in Organizational Change Research and Practice. Journal of Change Management, June, Vol. 9. No. 2.: p. $127-142$.

Atkinson, J. (2001): My Grief and Ours. Texas Monthly. Nov, Vol. 9. Issue 11.: p. $56-77$.

Bakacsi, Gy. (2004): Szervezeti magatartás és vezetés. Budapest: Aula Kiadó

Beer, M. - Nohria, N. (2000): Cracking the Code of Change. Harvard Business Review, May-June, Vol. 78. Issue 3.: p. $133-141$.

Blevins, S. (2008): A Personal Journey through the Grief and Healing Process with Virginia Satir, Dr. E. Kubler-Ross, and J. William Worden. The Satir Journal, Vol. 2. No. 2.: p. $89-105$.

Bolden, L. A. (2007): A Review of On Grief and Grieving. Finding the Meaning of Grief Through the Five Stages of Loss. Counseling and Values, April, Vol. 51. Issue 3.: p. 235 - 237.

Brown, P. B. (2013): The Five Stages of Retirement Planning Angst. New York Times, 2/10/2013. Issue 56043: p. 10.

Bryant, M. - Stensaker, I. (2011): The Competing Roles of Middle Management: Negotiated Order In the 
Context of Change. Journal of Change Management, 2011, Vol. 11. No. 3.: p. 353 - 373.

Burnes, B. (2011): Introduction. Why Does Change Fail, and What Can We Do About It? Journal of Change Management, December, Vol. 11. No. 4.: p. 445- 450.

By, R. T. - Diefenbach, T. - Klaner, P. (2008): Getting Organizational Change Right in Public Services. The Case of European Higher Education. Journal of Change Management, March, Vol. 8. No. 1.: p. $21-35$.

By, R. T. - Burnes, B. - Oswick, C. (2011): Change Management. The Road Ahead. Journal of Change Management, March, Vol. 11. No. 1.: p. 1-6.

Choi, M. (2011): Employees' Attitudes Toward Organizational Change: A Literature Review. Human Resource Management, 2011, Vol. 50. No. 4.: p. 479 -500 .

Coetsee, L. (1999): From Resistance To Commitment. Public Administrative Quarterly, Vol. 23. No. 2.: p. $204-222$.

Cummings, T. G. - Worley, C. G. (2001): Organization Development and Change. Boston, MA: South-Western College Publishing

Csedő, Z. (2006): Szervezeti változás és változásvezetés a folyamatos differenciálódás és integráció tükrében: az innovatív gyógyszeripar példája. PhD-disszertáció. Budapest: Budapesti Corvinus Egyetem

Dobák M. (1996): Szervezeti formák és vezetés. Budapest: KJK Kerszöv Kiadó

Drucker, P. (2001): 21. századi kihívások a vállalatirányításban. Budapest: HVG Kiadó

Drzensky, F. - Egold, N. - Van Dick, R. (2012): Ready for Change? A Longitudinal Study of Antecedents, Consequences and Contingencies of Readiness for Change. Journal of Change Management, 2012, Vol. 12. No. 1.: p. $95-111$.

Edmonson, A. C. (1996): Three Faces of Eden. The Persistence of Competing Theories and Multiple Diagnoses in Organizational Intervention Research. Human Relations, 1996, Vol. 49. No. 5.: p. 571 - 595.

Fineran, K. R. (2013): Helping Foster and Adopted Children to Grieve the Loss of Birthparents. A Case Study Example. Family Jornal Counseling and Therapy for Couples and Families, Oct, Vol. 20. Issue 4.: p. $369-375$.

Gastill, R.W. (1996): The Process of Divorce Recovery. A Review of the Research. Doctoral Thesis. Biola University. Forrás: http://files.eric.ed.gov/ fulltext/ED397365.pdf (Letöltés dátuma: 2015. március 16.)

Gelei A. (1996): Szervezeti keret és szervezeti változás - egy értelmezési kísérlet. Szociológiai Szemle, 1996/3-4.: p. 55 - 81.
Gelei, A. (2007): Szervezeti tanulás és szervezeti ellenállás. Egyetemi előadás. Budapesti Corvinus Egyetem, 2007. február 28.

Gerevich, J. (1989): A változás változása, avagy a problémamegoldás problémái. Előszó az első magyar kiadáshoz. in: Watzlawick, P. - Weakland, J. H. - Fisch, R. (2008): Változás. A problémák keletkezésének és megoldásainak elvei. Budapest: Animula Kiadó

Hisham Hashim, H. M. - Mei-Li, L. - Guan, N. C. (2013): A Journey from the Known to the Unknown. A Qualitative Study Approach. ASEAN Journal of Psychiatry, Jan/Jun, Vol. 14. Issue 1.: p. 1-6.

Jaros, S. (2010): Commitment to Organizational Change: A Critical Review. Journal of Change Management, 2010, Vol. 10. No. 1.: p. 79 - 108.

Karp, T. - Helgo, T. I. T. (2008): From Change Management to Change Leadership: Embaracing Chaotic Change in Public Service Organizations. Journal of Change Management, 2008, Vol. 8. No. 1.: p. $85-$ 96.

Karp, T. (2006): Transforming Organizations for Organic Growth: The DNA of Change Leadership. Journal of Change Management, 2006, Vol. 6. No. 1.: p. $3-20$.

Kerber, K. - Buono, A. F. (2005): Rethinking Organizational Change. Reframing the Challenge of Change Management. Organizational Development Journal, Fall, Vol. 23. No. 3.: p. 23 - 38.

Kerber, K. - Buono, A. F. (2010): Intervention and Organizational Change. Building Organizational Change Capacity. EBS Review, Nov 2010, Issue 27:: p. 9-21.

Kieser, Alfred (1995): A kontingenciaelmélet. in: Kieser, Alfred (szerk.): Szervezetelméletek. Budapest: Aula Kiadó: p. 212 - 241.

Kotter, J.P. (2008): Developing a Change-Friendly Culture. Leader to Leader, Spring, Vol. 2008 Issue 48.: p. $33-38$.

Kotter, J. P. (2012): Accelerate. How the Most Innovative Companies Capitalize on Today's Rapid-Fire Strategic Challenges - and Still Make Their Numbers. Harvard Business Review, November, Vol. 90. Issue 11.: p.44 - 58 .

Kübler-Ross, E. (1988): A halál és a hozzá vezető út. Budapest: Gondolat Kiadó

Kübler-Ross, E. - Kessler, D. (2005): On Grief and Grieving. Finding the Meaning of Grief Through the Five Stages of Loss. New York, NY: Scribner

Kübler-Ross, E. (2012): A halál mint ragyogó kezdet. Budapest: Bioenergetic Kft.

Leming, M. R. - Dickinson, G. E. (2007): Understanding Death, Dying and Bereavement. 6th ed. New York, NY: Wadsworth

Lofquist, E. A. (2011): Doomed to Fail. A Case Study of Change Implementation Collapse In the Norwegian 
Civil Aviation Industry. Journal of Change Management, Vol. 11. No. 2.: p. $223-243$.

Morrison, E. W. - Phelps, C. C. (1999): Taking Charge at Work: Extrarole Efforts to Initiate Workplace Change. Academy of Management Journal, Vol. 42. No. 4.: p. $403-419$.

Nutt, P. C. (1987): Identifying and Appraising How Managers Install Strategy. Strategic Management Journal, 1987, Vol. 8: p. 1 -14.

Pataki, B. (2013): Változásmemendzsment. Oktatási jegyzet. Budapesti Múszaki és Gazdaságtudományi Egyetem, 2013. Forrás: http://www.uti.bme.hu/ tantargyak?p_p_id=TantargyLista_WAR_bmeuti-p_p_lifecycle $=2-p \_p \_s t a t e=$ normal-p_p_mode $=-$ view-p_p_resource_id=download-p_p_cacheability=cacheLevelPage-_TantargyLista_WAR_bmeuti_id=61

Pettigrew, A. M. - Woodman, R. W. - Cameron, K. S. (2001): Studying Organizational Change and Development. Challenges for Future Research. Academy of Management Journal, Vol. 44. No. 4.: p. 697 - 713.

Phelan, M. W. (2005): Cultural Revitalization Movements in Organization Change Management. Journal of Change Management, Vol. 5. No. 1.: p. 47 - 56.

Poel, J. van der - Nel, P. (2011): Relevance of the Kübler-Ross Model to the Post-Injury Responses of competitive Athletes. South African Journey for Research in Sport, Physican Aducation and Recreation. Vol. 33. No.1.: p. $151-164$.

Robbins, S. P. - Judge, T. A. - Campbell, T. T. (2010): Organizational Behaviour. Harlow: Pearson

Rogers, J. (2011): Hard Times. Coaching at Work, Marc/ Apr, Vol. 6. Issue 2.: p. $32-34$
Russ, T. L. (2008): Communicating Change. A Review and Critical Analysis of Programmatic and Participatory Implementation Approaches. Journal of Change Management, Vol. 8. No. 3-4.: p. 199 - 211.

Sausner, R. (2008): „Red Flags” and The Five Stages of Grief. Bank Technology News, June, Vol. 21. Issue 6.: p. 13.

Schein, E. H. (1993): On Dialogue, Culture, and Organizational Learning. In: Reflections, Vol. 4., No. 4.: p. $27-37$.

Schein, E. H. (1996): Kurt Lewin's Change Theory in the Field: Notes Toward a Model of Managed Learning. Reflections, Vol. 1., No. 1.: p. $59-74$.

Schiffman, R. (2013): The Five Stages of Environmental Grief. Natural Life, March/Apr, Issue 150.: p. 8-12.

Sirkin, H. L. - Keenan, P. - Jackson, A. (2005): The Hard Side of Change Management. Harvard Business Review, Vol. 83. Issue 10.: p. 108 - 118.

Smaldone, M. C. - Uzzo, R. G. (2013): The Kübler-Ross Model, Physician Distress and Performance Reporting. Nature Review Urology, July, Vol. 10 (7): p. 425 -428 .

Watzlawick, P. - Weakland, J. H. - Fisch, R. (2008): Változás. A problémák keletkezésének és megoldásainak elvei. Budapest: Animula Kiadó

Wiggins, L. (2008): Managing the Ups and Downs of Change Communication. Strategic Communication Management, Vol. 13. No. 1.

Zaltman, G. - Duncan, R. (1977): Strategies for Planned Change, New York, NY: John Wiley and Sons 